\title{
Persistent Unilateral Sore Throat: Should It Be Included in the 2-Week Wait Referral Criteria by NICE
}

\author{
Ahmed Allam (iD) ${ }^{1,2}$ and Hazem Nijim ${ }^{3}$ \\ ${ }^{1}$ Otolaryngology Department, Sheffield Teaching Hospitals NHS Trust, UK \\ ${ }^{2}$ Department of Otolaryngology, Faculty of Medicine, Mansoura University, Egypt \\ ${ }^{3}$ Otolaryngology Department, Derby Teaching Hospitals, UK
}

Correspondence should be addressed to Ahmed Allam; ahmedallam2012@hotmail.com

Received 19 February 2019; Accepted 21 April 2019; Published 5 May 2019

Academic Editor: Sergio Motta

Copyright (C) 2019 Ahmed Allam and Hazem Nijim. This is an open access article distributed under the Creative Commons Attribution License, which permits unrestricted use, distribution, and reproduction in any medium, provided the original work is properly cited.

\begin{abstract}
Design and Setting. A retrospective study was conducted on all 2WW referrals made to our tertiary head and neck centre in a $12-$ month period. Methods. Sensitivity, specificity, and PPV of presenting complaints in H\&N cancer diagnosis using Excel ${ }^{\circledR}$ and the statistical package SPSS ${ }^{\circledR}$. Results. The sensitivity and specificity of 2005 NICE guidelines in detecting H\&N cancers were $91.2 \%$ and $59 \%$, respectively; their PPV was 9\%. The sensitivity and specificity of 2015 NICE guidelines were $75.4 \%$ and $71 \%$, respectively; their PPV was $10.3 \%$. Eight out of 85 patients who presented with unilateral sore throat for more than 4 weeks, with or without otalgia and normal otoscopy, had H\&N cancer (PPV 9.5\%). Conclusions. Although the 2015 NICE guidelines have a high rate in detecting $\mathrm{H} \& \mathrm{~N}$ cancers, consideration of reincluding unilateral sore throat in the referral criteria might be necessary.
\end{abstract}

\section{Introduction}

Following the 1998 White Paper, a new approach was established by Cancer Services Collaborative to facilitate quick review for patients with a suspected cancer [1]. In 2000, the Department of Health (DoH) introduced the guidelines and established 2 week wait (2WW) urgent referral for patients with symptoms suspicious of cancer in order to have an early diagnosis, treatment, and subsequently better prognosis for cancer patients in UK.

Regarding head and neck $(\mathrm{H} \& \mathrm{~N})$ cancer, the DoH sets ten symptoms with high possibility of cancer for H\&N referrals in 2000. These symptoms were refined to 8 symptoms by the National Institute for Health and Care Excellence (NICE) in 2005 [2]. In 2015, NICE published new guidance taking into consideration $3 \%$ positive predictive value (PPV), a threshold value to support the recommendations for pathway of suspected cancer. It refined symptoms to subsites with 5 symptoms suspecting head and neck cancer (HNC) for the urgent referral from general practice to secondary care [3] (Table 1).
Many studies have assessed the efficacy of $2 \mathrm{WW}$ pathway in the detection of cancer. Kumar et al. 2012 found that the cancer detection rate based on the 2000 NICE guidelines ranged from $6.3 \%$ to $14.6 \%$ [4]. Another study conducted on $41232 \mathrm{WW}$ referred patients found that $6 \%$ of them had $\mathrm{H} \& \mathrm{~N}$ cancer diagnosis [5].

In our study, we focus on the efficacy of NICE guidelines in $\mathrm{H} \& \mathrm{~N}$ cancer detection rate, compare the 2015 and 2005 NICE in detecting H\&N cancer, and evaluate the positive predictive value (PPV) of persistent unilateral sore throat more than 4 weeks with or without otalgia, a symptom that was not included in the 2015 NICE guidelines.

\section{Materials and Methods}

We retrospectively studied all $2 \mathrm{WW}$ referrals seen in our H\&N tertiary centre in a 12-month period (January 2016 to December 2016). Data was collected from hospital electronic database and patients' medical notes. We excluded patients with thyroid cancer, lymphoma, previous H\&N cancers; those who did not attend their appointments or where data 
TABLE 1: Symptoms suspecting cancer for urgent referral.

\begin{tabular}{|c|c|c|}
\hline DoH 2000 Guidelines & NICE Guidelines 2005 & NICE Guidelines 2015 \\
\hline $\begin{array}{l}\text { Ulceration of oral mucosa persisting } \\
\text { for }>3 \text { weeks }\end{array}$ & $\begin{array}{l}\text { Ulceration of oral mucosa persisting } \\
\text { for }>3 \text { weeks }\end{array}$ & $\begin{array}{l}\text { Ulceration of oral mucosa persisting } \\
\text { for }>3 \text { weeks }\end{array}$ \\
\hline $\begin{array}{l}\text { All red or red and white patches of } \\
\text { the oral mucosa }\end{array}$ & $\begin{array}{l}\text { Unexplained red and white patches } \\
\text { (including suspected lichen planus) } \\
\text { of the oral mucosa }\end{array}$ & $\begin{array}{c}\text { A red or red and white patch in the } \\
\text { oral cavity consistent with } \\
\text { erythroplakia or } \\
\text { erythroleukoplakia }\end{array}$ \\
\hline Hoarseness persisting for $>6$ weeks & $\begin{array}{c}\text { Hoarseness persists for more than } 3 \\
\text { weeks }\end{array}$ & $\begin{array}{c}\text { Aged } 45 \text { or above persistent } \\
\text { unexplained hoarseness }\end{array}$ \\
\hline $\begin{array}{l}\text { Unresolving neck masses for }>3 \\
\text { weeks }\end{array}$ & $\begin{array}{c}\text { Unresolving neck lump for }>3 \\
\text { weeks }\end{array}$ & $\begin{array}{l}\text { Persistent unexplained lump in the } \\
\text { neck }\end{array}$ \\
\hline $\begin{array}{l}\text { Unexplained tooth mobility not } \\
\text { associated with periodontal disease }\end{array}$ & $\begin{array}{l}\text { Unexplained tooth mobility not } \\
\text { associated with periodontal disease }\end{array}$ & Lump in the lip or oral cavity \\
\hline $\begin{array}{l}\text { Unilateral nasal obstruction } \\
\text { particularly when associated with } \\
\text { purulent discharge }\end{array}$ & $\begin{array}{l}\text { Unexplained persistent sore or } \\
\text { painful throat }\end{array}$ & \\
\hline Cranial neuropathies & $\begin{array}{c}\text { Persistent swelling in the parotid or } \\
\text { submandibular gland }\end{array}$ & \\
\hline Orbital masses & $\begin{array}{l}\text { Unilateral unexplained pain in the } \\
\text { head and neck } \\
\text { area for more than } 4 \text { weeks, } \\
\text { associated with otalgia but with } \\
\text { normal otoscopy }\end{array}$ & \\
\hline \multicolumn{3}{|l|}{ Dysphagia persisting for 3 weeks } \\
\hline $\begin{array}{l}\text { Oral swellings persisting for }>3 \\
\text { weeks }\end{array}$ & & \\
\hline
\end{tabular}

TABLE 2: Cancer detection rate in patients referred through 2 ww pathway and compliant with NICE guidelines.

\begin{tabular}{|c|c|c|c|c|c|c|}
\hline \multirow{2}{*}{$\begin{array}{l}\text { Symptoms } \\
\text { Neck lump: new or } \\
\text { persisting for }>3 \text { weeks }\end{array}$} & \multicolumn{2}{|c|}{ Frequency (\%) } & \multirow{2}{*}{$\begin{array}{c}\begin{array}{c}\text { Cancer } \\
\text { positive }\end{array} \\
32\end{array}$} & \multirow{2}{*}{$\begin{array}{c}\text { Included in } 2005 \\
\text { NICE guidelines } \\
\text { Yes }\end{array}$} & \multirow{2}{*}{$\begin{array}{c}\text { Included in } 2015 \\
\text { NICE guidelines } \\
\text { Yes }\end{array}$} & \multirow{2}{*}{$\begin{array}{c}\mathrm{PPV}(\%) \\
12.2 \%\end{array}$} \\
\hline & 270 & $19.8 \%$ & & & & \\
\hline $\begin{array}{l}\text { Hoarseness Persisting for }> \\
3 \text { weeks }\end{array}$ & 147 & $11.1 \%$ & 10 & Yes & Yes & $6.8 \%$ \\
\hline $\begin{array}{l}\text { Persistent painful sore } \\
\text { throat }\end{array}$ & 137 & $10 \%$ & 9 & Yes & No & $6.5 \%$ \\
\hline $\begin{array}{l}\text { Unilateral neck pain and } \\
\text { otalgia with normal } \\
\text { otoscopy }\end{array}$ & 23 & $1.3 \%$ & 1 & Yes & No & $4.3 \%$ \\
\hline Total & 577 & & 52 & & & $9 \%$ \\
\hline
\end{tabular}

was missing and those cases managed by our oral and maxillofacial colleagues.

The collected data were analysed using Excel $^{\circledR}$ (Microsoft, Redmond, WA, US) and the statistical package SPSS ${ }^{\circledR} .2010$ and 2015 NICE Guidance's sensitivity, specificity, and positive predictive value (PPV) were calculated.

\section{Results}

3.1. 2-Week Wait Referrals. A total number of 1553 patients were referred from primary care general practitioners (GP) through $2 \mathrm{WW}$ pathway to our $\mathrm{H} \& \mathrm{~N}$ centre within a 12 month period. We excluded 186 patients who did not fulfill inclusion criteria. Out of the remaining 1367 patients, 627 were males (45.8\%), and 740 were females (54.2\%). Their mean age was 59 (age range 16-95). $82.3 \%$ were above 45 years of age.

3.2. Cancer Detection Rates through the $2 W W$ Pathway. Only 57 out of the 1367 patients $(4.2 \%)$ we included in this study were diagnosed with $\mathrm{H} \& \mathrm{~N}$ cancers. The cancer detection rate of the 2005 guidelines was $9 \%(52 / 577)$ and the detection rate of the 2015 guidelines was 10\% (42/417).

The commonest symptoms referred via the $2 \mathrm{WW}$ pathway and those with high PPV for detection of cancer are presented in Tables 2 and 3. For example, we have the following:,

(1) Those patients presented with a new or persisting neck lump for > 3 weeks: 32 out of 270 patients, who were 
TABLE 3: Cancer detection rate in a patient referred through 2 ww pathway and NOT compliant with NICE guidelines.

\begin{tabular}{|c|c|c|c|c|c|c|}
\hline \multirow{2}{*}{$\begin{array}{l}\text { Symptoms } \\
\text { The sensation of a lump } \\
\text { in the throat }\end{array}$} & \multicolumn{2}{|c|}{ Frequency (\%) } & \multirow{2}{*}{$\begin{array}{c}\begin{array}{c}\text { Cancer } \\
\text { positive }\end{array} \\
0\end{array}$} & \multirow{2}{*}{$\begin{array}{c}\text { Included in } 2005 \\
\text { NICE guidelines } \\
\text { No }\end{array}$} & \multirow{2}{*}{$\begin{array}{c}\text { Included in } 2015 \\
\text { NICE guidelines } \\
\text { No }\end{array}$} & \multirow{2}{*}{$\begin{array}{c}\text { PPV (\%) } \\
0 \%\end{array}$} \\
\hline & 181 & $14.3 \%$ & & & & \\
\hline Intermittent hoarseness & 115 & $9.1 \%$ & 0 & No & No & $0 \%$ \\
\hline Intermittent sore throat & 78 & $5.7 \%$ & 0 & No & No & $0 \%$ \\
\hline Discomfort in throat & 78 & $5.7 \%$ & 0 & No & No & $0 \%$ \\
\hline $\begin{array}{l}\text { Unilateral nasal } \\
\text { obstruction and discharge }\end{array}$ & 53 & $3.9 \%$ & 1 & No & No & $1.89 \%$ \\
\hline Unilateral OME & 42 & $3.1 \%$ & 0 & No & No & $0 \%$ \\
\hline Dysphagia for $>3$ weeks & 33 & $2.4 \%$ & 2 & No & No & $6.06 \%$ \\
\hline $\begin{array}{l}\text { Intermittent sore throat } \\
\text { and hoarseness }\end{array}$ & 33 & $2.4 \%$ & 0 & No & No & $0 \%$ \\
\hline $\begin{array}{l}\text { Unilateral nasal } \\
\text { obstruction only }\end{array}$ & 27 & $2.1 \%$ & 0 & No & No & $0 \%$ \\
\hline $\begin{array}{l}\text { Presence of blood in the } \\
\text { mouth }\end{array}$ & 24 & $1 \%$ & 1 & No & No & $4.17 \%$ \\
\hline $\begin{array}{l}\text { Unilateral nasal } \\
\text { discharge only }\end{array}$ & 22 & $1.6 \%$ & 0 & No & No & $0 \%$ \\
\hline $\begin{array}{l}\text { Unexplained septum } \\
\text { ulcer }\end{array}$ & 18 & $1.3 \%$ & 0 & No & No & $0 \%$ \\
\hline $\begin{array}{l}\text { Persistent unexplained } \\
\text { facial palsy }\end{array}$ & 18 & $1.2 \%$ & 1 & No & No & $5.56 \%$ \\
\hline Unilateral neck pain & 16 & $1.2 \%$ & 0 & No & No & $0 \%$ \\
\hline Tightness throat & 12 & $0.9 \%$ & 0 & No & No & $0 \%$ \\
\hline Smell disturbance & 11 & $0.8 \%$ & 0 & No & No & $0 \%$ \\
\hline $\begin{array}{l}\text { Unexplained septum } \\
\text { Perforation }\end{array}$ & 9 & $0.7 \%$ & 0 & No & No & $0 \%$ \\
\hline $\begin{array}{l}\text { Persistent unexplained } \\
\text { sore nose }\end{array}$ & 9 & $0.7 \%$ & 0 & No & No & $0 \%$ \\
\hline Taste disturbance & 6 & $0.4 \%$ & 0 & No & No & $0 \%$ \\
\hline Blood in the ear & 5 & $0.4 \%$ & 0 & No & No & $0 \%$ \\
\hline Total & 790 & & 5 & & & \\
\hline
\end{tabular}

referred with this symptom, were diagnosed with cancer (PPV 12.2\%).

(2) Hoarseness of voice persisting more than three weeks: 10 out of 147 patients who were referred with this symptom were diagnosed with cancer (PPV 6.8\%).

(3) Persistent sore throat: 9 out of 137 patients who were referred with this symptom were diagnosed with cancer (PPV 6.5\%).

3.3. Efficacy of 2005 and 2015 NICE Guidelines. The sensitivity and specificity of the 2005 NICE guidelines were found to be $91.2 \%$ and $59 \%$, respectively, in detecting $\mathrm{H} \& \mathrm{~N}$ cancers via the $2 \mathrm{WW}$ pathway. Their PPV was $9 \%$. The sensitivity and specificity of the 2015 NICE guidelines were found to $75.4 \%$ and $71 \%$, respectively. Their PPV was $10.3 \%$.

3.4. Noncancer Diagnoses following a $2 \mathrm{WW}$ Referral. The most common noncancer diagnosis in our $2 \mathrm{WW}$ referrals was laryngopharyngeal reflux (454 patients). No abnormality was found in 241 patients. Other diagnoses can be seen in Table 4

3.5. Analysis of Persistent Sore Throat. We received 137 referrals of patients with a persistent sore throat. 9 of them were found to have $\mathrm{H} \& \mathrm{~N}$ cancer. In further analysis, we found the following (Table 5):

(i) $17(12.4 \%)$ patients had persistent unilateral sore throat for less than four weeks: none of them was diagnosed with $\mathrm{H} \& \mathrm{~N}$ cancer.

(ii) $57(41.6 \%)$ patients had persistent unilateral sore throat more than four weeks. Cancer was detected in 5 patients (PPV 8.8\%).

(iii) $28(20.4 \%)$ patients had persistent unilateral sore throat with otalgia with normal otoscopy. Cancer was detected in 3 patients (PPV 10.5\%).

(iv) The remaining 35 patients had a nonspecific persistent sore throat. One patient was cancer positive (PPV 2\%).

Overall, unilateral sore throat for more than 4 weeks with or without otalgia and normal otoscopy has a high PPV or $9.5 \%$. 
TABLE 4: Final diagnosis of patients referred through 2 ww pathway.

\begin{tabular}{|c|c|c|}
\hline Diagnosis & Frequency & Percent \\
\hline Head and neck malignancy & 57 & $4.2 \%$ \\
\hline Laryngopharyngeal Reflux & 454 & $33.2 \%$ \\
\hline No abnormality / reassured & 240 & $17.6 \%$ \\
\hline Functional dysphonia & 96 & $7 \%$ \\
\hline Globus pharyngus & 76 & $5.6 \%$ \\
\hline Reactive /Normal lymph nodes & 57 & $2.8 \%$ \\
\hline Benign salivary glands lesions & 38 & $2.8 \%$ \\
\hline Idiopathic unilateral vocal cord Palsy & 36 & $2.6 \%$ \\
\hline Reinke's oedema & 25 & $1.8 \%$ \\
\hline Infections & 23 & $1.7 \%$ \\
\hline Vocal cord nodules & 19 & $1.4 \%$ \\
\hline Septal deviation & 17 & $1.3 \%$ \\
\hline Cervical lipoma & 16 & $1.2 \%$ \\
\hline Laryngeal polyps & 12 & $0.9 \%$ \\
\hline Sebaceous Cysts & 12 & $0.9 \%$ \\
\hline Retention tonsillar cysts & 10 & $0.8 \%$ \\
\hline Cervical TB & 7 & $0.5 \%$ \\
\hline Hyperkeratosis vocal cord & 7 & $0.5 \%$ \\
\hline Laryngeal papillomatosis & 5 & $0.4 \%$ \\
\hline Mild cord dysplasia & 5 & $0.4 \%$ \\
\hline Moderate vocal cord dysplasia & 3 & $0.2 \%$ \\
\hline Cervical toxoplasmosis & 2 & $0.1 \%$ \\
\hline Bronchogenic carcinoma & 2 & $0.1 \%$ \\
\hline Granuloma arytenoid & 2 & $0.1 \%$ \\
\hline Vallecular cysts & 2 & $0.1 \%$ \\
\hline Neurofibroma & 2 & $0.1 \%$ \\
\hline Carotid body tumour & 2 & $0.1 \%$ \\
\hline Thyroglossal cyst & 2 & $0.1 \%$ \\
\hline Other diagnosis & 138 & $10.1 \%$ \\
\hline Total & 1367 & $100 \%$ \\
\hline
\end{tabular}

TABle 5: Analysis of a persistent sore throat.

\begin{tabular}{|c|c|c|c|c|}
\hline \multirow{2}{*}{$\begin{array}{l}\text { Symptom } \\
\text { Unilateral pain in throat }<4 \text { weeks }\end{array}$} & \multicolumn{2}{|c|}{ Frequency $(\%)$} & \multicolumn{2}{|c|}{ Cancer positive } \\
\hline & 17 & $12.4 \%$ & 0 & $0 \%$ \\
\hline Unilateral pain in throat $>4$ weeks & 57 & $41.6 \%$ & 5 & $8.8 \%$ \\
\hline $\begin{array}{l}\text { Unilateral pain in throat and otalgia with normal } \\
\text { otoscopy }\end{array}$ & 28 & $20.4 \%$ & 3 & $10.7 \%$ \\
\hline Nonspecific Sore throat & 35 & $25.5 \%$ & 1 & $2 \%$ \\
\hline Total & 137 & $100 \%$ & 9 & $6.5 \%$ \\
\hline $\begin{array}{l}\text { Unilateral pain in the throat more than } 4 \text { weeks } \\
\text { with or without otalgia with normal otoscopy }\end{array}$ & $85 / 137$ & $62 \%$ & 8 & $9.5 \%$ \\
\hline
\end{tabular}

\section{Discussion}

\subsection{Comparison with Existing Literature}

4.1.1. Cancer Detection Rates. 2015 NICE Guidelines had lower sensitivity (75.4\%) in comparison with 2005 guidelines (91\%); however, 2015 guidance has higher PPV for diagnosing cancer and higher specificity.
4.1.2. Persistent Unilateral Pain in Head and Neck. Persistent unilateral sore throat with otalgia is an important presenting complaint for diagnosing $\mathrm{H} \& \mathrm{~N}$ cancer, especially for oropharyngeal, laryngeal, and hypopharyngeal malignancy [6].

In our study analysis, unilateral sore throat for more than 4 weeks with or without otalgia had a 9.5\% PPV in $\mathrm{H} \& \mathrm{~N}$ cancer diagnosis. Tikka et al. [7] showed higher PPV (14.2\%) for unilateral persistent neck pain more than 4 weeks with 
or without otalgia and normal otoscopy, but this finding was based on a smaller number of patients (49). This symptom of unilateral sore throat was not included in 2015 NICE guidelines for $2 \mathrm{WW}$ referral criteria. Although there has been no official reason for that, we assume that general practice is overwhelmed with a wide variety of sore throat presentations. Therefore onward referral to a tertiary centre might not necessarily be the best option in all these cases. Our study suggests that unilateral sore throat for more than 4 weeks has a high PPV for diagnosing cancer and we would recommend that this symptom is added on the following NICE guidelines on $2 \mathrm{WW}$ for $\mathrm{H} \& \mathrm{~N}$ cancers.

4.2. Strengths and Limitations. The major drawback of our study is that it is a retrospective study. Most published studies on $2 \mathrm{WW}$ referral pathways were retrospective; a prospective design would offer more robust outcomes. Data were recorded in the patient first appointment by different grades of ENT doctors. This could be considered bias in methodology. This study is unique as it has included the highest number of referred patients in a single centre, since the 2015 NICE guidelines were published.

This was a retrospective cohort and the population of this study was limited to the patients who were only referred through $2 \mathrm{WW}$ pathway as a $2 \mathrm{ww}$ to our Head and Neck Unit at Sheffield Teaching Hospitals, Sheffield.

Unfortunately, we do not have data about the total numbers of all patients with sore throat admitted to our ENT not as a $2 \mathrm{WW}$. This was out of the study objectives. I think it would be a great idea to perform a study looking at that but that would mean lots of challenges (we see more than 25.000 new referrals to ENT at Sheffield Teaching Hospitals per year)

We found that the majority of these patient were referred as a $2 \mathrm{WW}$ from primary care after exhausting all treatment medications (various lots of antibiotics and pain killers) and patients are still symptomatic; however, we could not analyse it as it was missed in some patients, a lot depending on how well the patients were interviewed regards to symptoms and previous treatments received.

Other factors which could have triggered the $2 \mathrm{ww}$ referral were smoking and alcohol history.

Head and neck cancer symptoms are unspecific; oropharyngeal cancers can be diagnosed in patients presenting only with sensation of lump with no other ENT symptoms.

However, from our study we would recommend our colleagues in primary care to have a very low threshold to refer a patient as a $2 \mathrm{WW}$ for being suspicious of head and neck cancer especially if they have unilateral sore throat for $>5$ weeks and especially if that has become associated with otalgia with normal otoscopy.

Our colleagues in primary care face many challenging in screening head and neck cancer patients taking in consideration that many symptoms are unspecific and they have very limited time for patients which could make taking a comprehensive clinical history very challenging.

4.3. Implications for Research and/or Practice. $2 \mathrm{WW}$ referrals have a high detection rate of cancers if they are compliant with 2015 NICE guidelines (10\%). We recommend investing more resources in more education in $\mathrm{H} \& \mathrm{~N}$ cancer symptoms for general practitioners. This can be achieved with the help of an 'e-Learning for Healthcare' module online, as well as continuous feedback from $\mathrm{H} \& \mathrm{~N}$ colleagues (via written feedback, meetings, and telephone advice). The aim would be to be confident in making (or ruling-out) a cancer diagnosis have more appropriate $2 \mathrm{WW}$ referrals [8].

Open discussion between GPs and patients around cancer should be encouraged when referring them for symptoms suspicious of cancer in order to line up referrals with NICE guidelines and to decrease patients pressure on primary practice for urgent referrals [9].

\section{Conclusion}

The newest NICE guidelines for an urgent referral via the 2WW pathway in 2015 have higher specificity and positive predictive value for cancers in comparison to previous guidelines, possibly because it narrowed the referral items to only 5 symptoms. Our study confirmed the low cancer detection rate via the $2 \mathrm{WW}$ urgent referral pathway, similar to previous studies $[7,10,11]$.

Persistent unilateral sore throat for more than 4 weeks with or without otalgia with normal otoscopy was included in the 2005 NICE guidelines for an urgent referral via the 2WW pathway but not in the 2015 NICE updates with no cited reasons [7]. This study raises our concern that this symptom has a high PPV $(9.5 \%)$ of positive cancer and should be reconsidered when designing future guidelines.

\section{Summary}

(i) The newest NICE guidelines for an urgent referral via the $2 \mathrm{WW}$ pathway in 2015 have higher specificity and positive predictive value for cancers in comparison to previous guidelines.

(ii) Persistent unilateral sore throat for more than 4 weeks with or without otalgia with normal otoscopy has high cancer predictive value and was not included in NICE guidelines 2015.

(iii) Persistent sore throat can be reconsidered to be included in the 2-week wait referral criteria updates by NICE.

\section{Data Availability}

The data used to support the findings of this study are available from the corresponding author upon request, and the patient's data used to support these findings are included in the article.

\section{Ethical Approval}

The analysis was based on existing data that had been anonymised and therefore did not require the approval of the ethics committee. 


\section{Conflicts of Interest}

The authors have declared no conflicts of interest.

\section{Authors' Contributions}

Ahmed Allam carried out conception and design, analysis and interpretation, writing the article, critical revision of the article, data collection, and literature search. Hazem Nijim carried out conception and design, analysis and interpretation, writing the article, critical revision of the article, data collection, literature search, and final approval of the article.

\section{Acknowledgments}

The institution where work was preformed is the Department of Otolaryngology, Sheffield Teaching Hospitals, Sheffield, UK.

\section{References}

[1] Health Do. The new NHS: modern, dependable: executive summary: Department of Health; 1997.

[2] National Institute for Health and Clinical Excellence, Referral Guidelines for Suspected Cancer, NICE, London, UK, 2005.

[3] National Institute for Health and Clinical Excellence, Suspected Cancer: Recognition and Referral, NICE, London, UK, 2015.

[4] R. Kumar, M. Drinnan, H. Mehanna, and V. Paleri, "Efficacy of the two-week wait referral system for head and neck cancer: a systematic review," The Bulletin of the Royal College of Surgeons of England, vol. 94, no. 3, pp. 101-105, 2012.

[5] B. Y. Wong, S. Fischer, and H. E. Cruickshank, "Clinical outcome of head and neck cancer patients: a comparison between ENT patients referred via the 2 weeks wait pathway and alternative routes in the UK health system," European Archives of Oto-Rhino-Laryngology, vol. 274, no. 1, pp. 415-420, 2017.

[6] H. Mehanna, V. Paleri, C. M. West, and C. Nutting, "Head and neck cancer-Part 1: epidemiology, presentation, and prevention," British Medical Journal, vol. 341, article c4684, 2010.

[7] T. Tikka, P. Pracy, and V. Paleri, "Refining the head and neck cancer referral guidelines: A two centre analysis of 4715 referrals," British Journal of Oral and Maxillofacial Surgery, vol. 54, no. 2, pp. 141-150, 2016.

[8] P. Pracy, L. Prichard, and I. Whitehead, "The 2-week wait head neck cancer referrals: is this system working?" The Otorhinolaryngologist, pp. 182-186, 2013.

[9] J. Banks, F. M. Walter, N. Hall, K. Mills, W. Hamilton, and K. M. Turner, "Decision making and referral from primary care for possible lung and colorectal cancer: a qualitative study of patients' experiences," British Journal of General Practice, vol. 64, no. 629, pp. e775-e782, 2014.

[10] M. Lyons, J. Philpott, I. Hore, and G. Watters, "Audit of referrals for head and neck cancer - the effect of the 2-week, fast track referral system," Clinical Otolaryngology \& Allied Sciences, vol. 29, no. 2, pp. 143-145, 2004.

[11] C. McKie, U. A. Ahmad, S. Fellows et al., "The 2-week rule for suspected head and neck cancer in the United Kingdom: referral patterns, diagnostic efficacy of the guidelines and compliance," Oral Oncology, vol. 44, no. 9, pp. 851-856, 2008. 


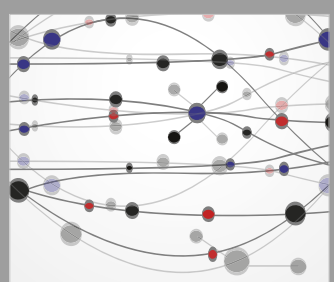

The Scientific World Journal
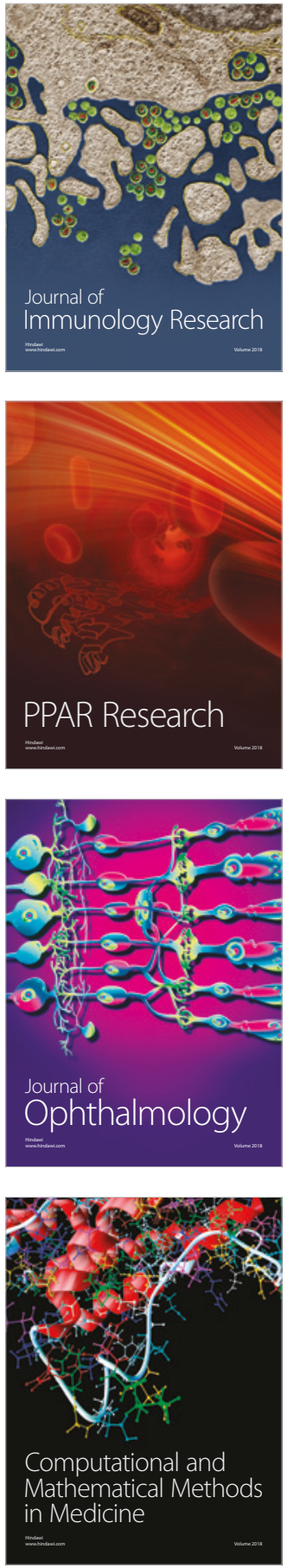

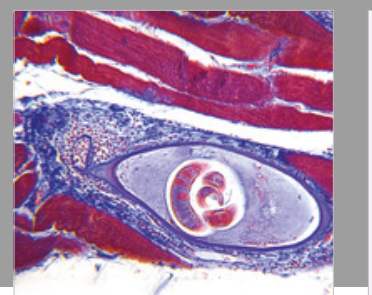

Gastroenterology Research and Practice

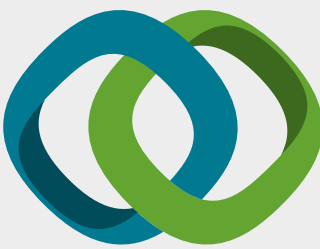

\section{Hindawi}

Submit your manuscripts at

www.hindawi.com
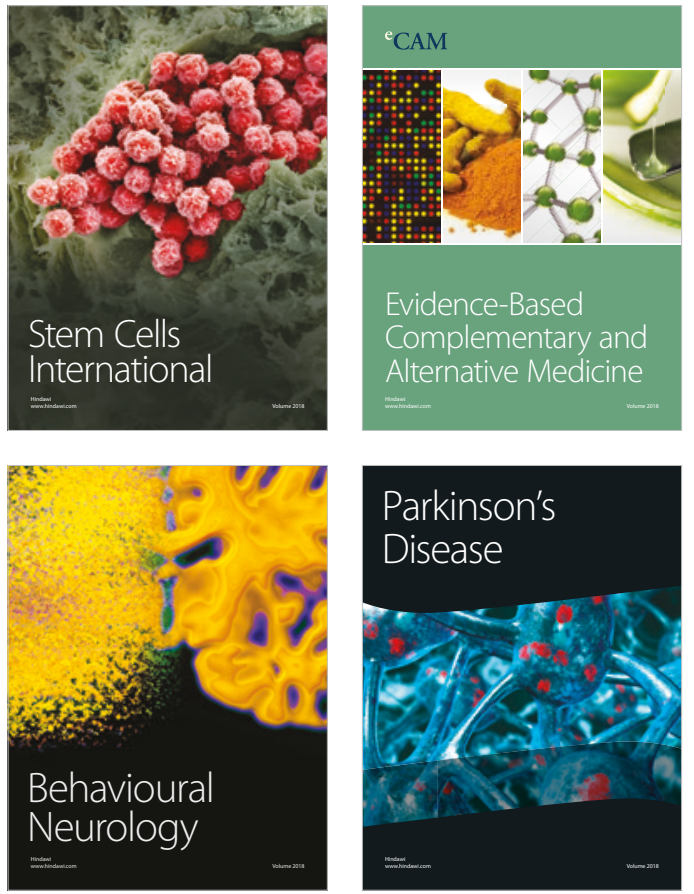

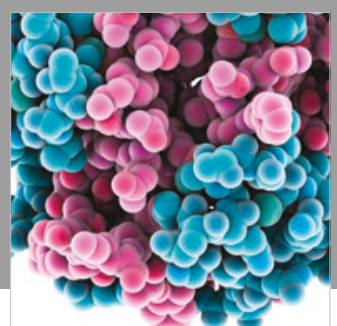

ournal of

Diabetes Research

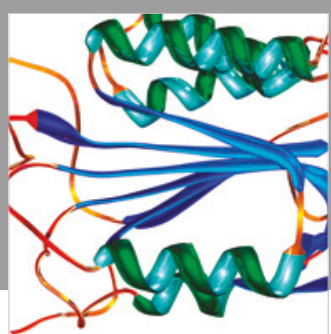

Disease Markers
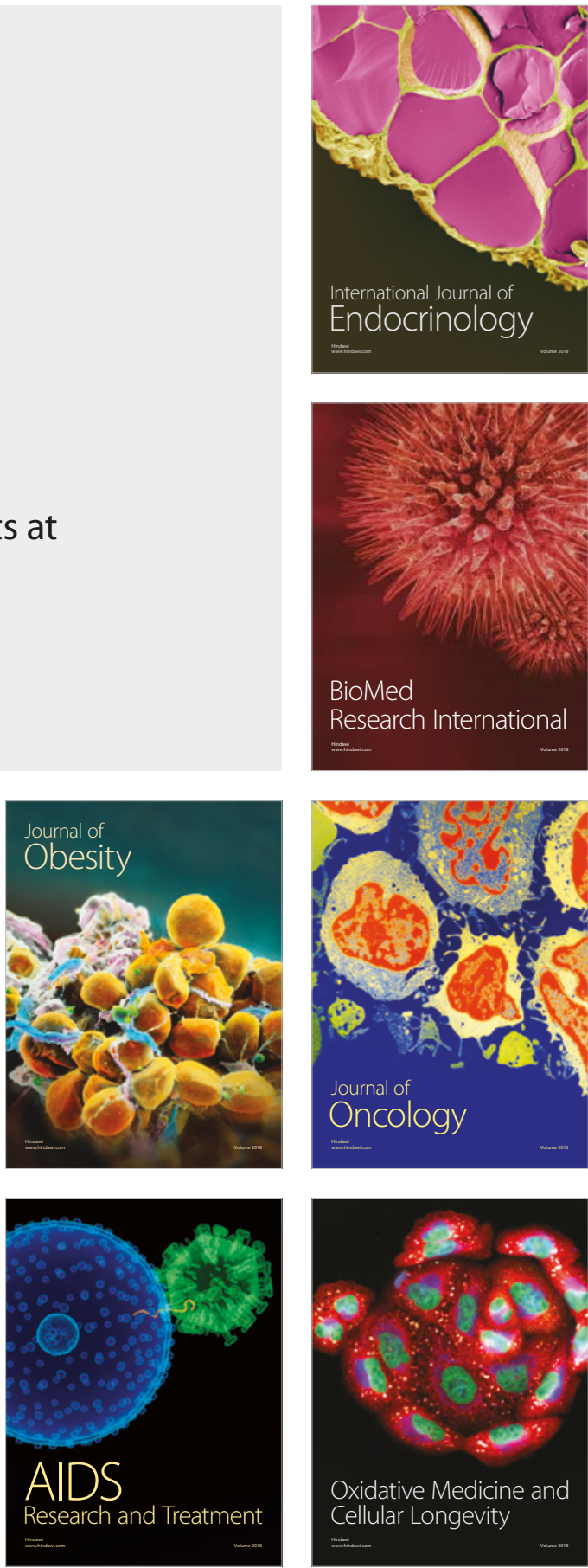